\title{
A Comprehensive review on Pharmacological Profile of Butea monosperma (Lam.) Taub
}

\author{
Brijesh Kantilal Sutariya, Madhusudan Natvarlal Saraf* \\ Department of Pharmacology, Bombay College of Pharmacy, Kalina, Santacruz (East), Mumbai-400068, Maharashtra, India.
}

\begin{tabular}{|c|c|}
\hline ARTICLE INFO & ABSTRACT \\
\hline Article history: & \multirow{7}{*}{$\begin{array}{l}\text { Butea monosperma (Lam.) Taub belong to family Fabaceae, widely distributed in India and in all Asian } \\
\text { hemispheres. It is a plant that has been electively used in traditional Asian medicines for centuries. It has been } \\
\text { used for the treatment of different ailments such as cancer, diabetes, diarrhoea, dysentery, fever and jaundice. } \\
\text { Recent in vivo and in vitro studies have indicates its anti-diabetic, anti-cancer, anti-inflammatory, anti-asthmatic, } \\
\text { anti-oxidant, anti-convulsant, anti-microbial, anti-viral and hepatoprotective properties. The aerial part of the } \\
\text { plant contains a large number of phytochemicals mainly flavonoids, lactones, diterpenoids, diterpene glycosides } \\
\text { and phytosterols. This review will discuss the recent findings on the mechanisms, traditional and folk medicinal } \\
\text { uses and remarkable biological activity of Butea monosperma. }\end{array}$} \\
\hline Received on: $14 / 07 / 2015$ & \\
\hline Revised on: 04/08/2015 & \\
\hline Accepted on: $24 / 08 / 2015$ & \\
\hline Available online: $27 / 09 / 2015$ & \\
\hline Key words: & \\
\hline $\begin{array}{l}\text { Butea monosperma; } \\
\text { traditional uses; anti-diabetic; } \\
\text { anti-inflammatory. }\end{array}$ & \\
\hline
\end{tabular}

\section{INTRODUCTION}

Relationship between human and medicinal plants have been emphasized by Ayurveda since the origin of mankind. Humans have depended on plants for their basic needs such as food-stuffs, shelters, clothing, fertilizers, flavors and fragrances and medicines (Gurib-Fakim, 2006).

Ayurveda is one of the oldest medical systems in the world, providing innumerable leads to find active and therapeutically useful compounds for drug development from plants. Currently, the use of herbal medicines is wide spread in developing as well as developed countries due to its natural source and limited adverse effects (Ekor, 2013).

Medicinal plant drug discovery continues to provide new and important leads against various pharmacological targets including diabetes, cancer, malaria, cardiovascular diseases and neurological disorders (Ramawat et al., 2009). Interest in herbal drugs and natural medicine is undergoing a renaissance at the present time.

\footnotetext{
* Corresponding Author

Madhusudan NatvarlalSaraf, Department of Pharmacology, Bombay College of Pharmacy, Kalina, Santacruz (East), Mumbai-400068,

Maharashtra, India.Email: madhusudan.saraf@gmail.com
}

There are number of medicinal plants in Ayurveda that are recommended for the treatment of various disorders, one of them being Butea monosperma (Lam.) Taub commonly known is 'Flame of forest' and Bastard Teak. It is a medium- sized tree belonging to family Fabaceae.

This tree has long been known to the Hindus under the Sanskrit name of palasha, as possessing precious therapeutic properties. Almost all the parts of Butea monosperma are being used since decades in medicine and for other purposes. It is considered as a good source of gum, resin, food, fibre, dye and traditionally being use for the treatment of number of diseases such as cancer, diabetes diarrhoea and dysentery (Burlia et al., 2007).

The other genus of Butea includes Butea monosperma, Butea frondosa, Butea parviflora, Butea superba and widely distributed throughout India (Khare, 2007). The aim of the current review is to discuss the taxonomy, phytochemistry and pharmacology of Butea monosperma (Lam.) Taub.

\section{TAXONOMY}

\author{
Scientific Name (Khare, 2007) \\ Butea monosperma (Lam.) Taub (Synonym Name- Butea \\ frondosa Koenig ex Roxb)
}


Vernacular Name (The Ayurvedic Pharmacopoeia)

Paalasha, Kimshuka, Raktapushpaka (Ayurvedic); Dhaak, Samagh Dhaak, Kamarkas (Unani); Palasam, Purasus (Tamil); Kimsuka, Brahma Vrksa, Karaka (Sanskrit); Flame of forest, Parrot Tree (English); Palas, Tesu, Dhak (Hindi); Kimsuk (Bengali); Keshu (Punjabi); Moduga (Telugu); Kesudo (Gujarati); Palashpapra (Urdu); Muthuga (Kannada.); Pangong (Manipuri)

\begin{tabular}{ll} 
Botanical Classification (The Ayurvedic Pharmacopoeia) \\
\hline Kingdom & Plantae \\
Class & Magnoliopsida \\
Order & Fabales \\
Family & Fabaceae \\
Genus & Butea \\
Division & Magnoliophyta \\
Species & Monosperma (Lam.) Taubert \\
\hline
\end{tabular}

\section{DISTRIBUTION}

Butea monosperma (Lam.) Taub is a medium-sized deciduous tree growing throughout India, South Asia, Indonesia, Japan, Laos, Myanmar, Nepal, Sri Lanka, Thailand and Vietnam. It is commonly found up to an altitude of $1200 \mathrm{~m}$ except in very arid regions (Khare, 2007). Generally it grows gregariously on open grasslands and scattered in mixed forest. Plantations can be raised both on irrigated and dry lands. It grows on a wide variety of soils including shallow, gravelly sites, black cotton soil, clay loams, and even saline or waterlogged soils. Seedlings thrive best on a rich loamy soil with $\mathrm{pH}$ 6-7 under high temperature and relative humidity (Burlia et al., 2007; Hocking, 1993).

\section{DESCRIPTION}

Butea monosperma (Lam.) Taub is an erect, slow growing, deciduous tree reaching 5 to $8 \mathrm{~m}$ with a crooked trunk and irregular branches (Figure 1).

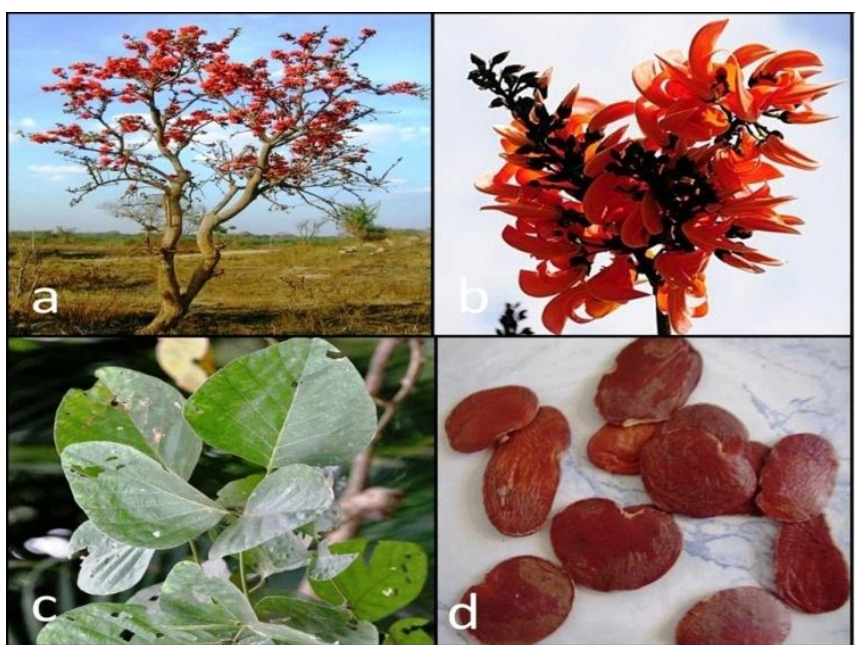

Fig. 1: Butea monosperma (a) tree (b) flowers (c) leaves (d) seeds.

It attains a diameter of about 20 to $40 \mathrm{~cm}$ when it matures at the age of about 50 years (Rana et al., 2012). The leaves are large, stipulate and 3-foliate. Leaflets are obtuse, glabrous above, finely silky and conspicuously reticulately veined beneath with cunnate or deltoid base. Flowers are large, bright crimson orange colour and 2 to $4 \mathrm{~cm}$ in diameter. It start appearing in february and stay on nearly up to the end of April. Pods are stalked 12.5-20 by $2.5-5 \mathrm{~cm}$, thickened at the sutures, reticulately veined argenteocanescent: stalk $2 \mathrm{~cm}$ long (Burlia et al., 2007). The seeds are flat, kidney shaped, 25 to $40 \mathrm{~mm}$ long, 1 to $3 \mathrm{~mm}$ wide, and 1.5 to 2 $\mathrm{mm}$ thick. It is dark reddish-brown in colour, thin, glossy; hilum clear, situated near middle of seed; odour, faint; taste, slightly acrid and bitter (The Ayurvedic Pharmacopoeia).

\section{AYURVEDIC PREPARATION}

Butea monosperma (Lam.) Taub is used as one of the important ingratiates in most commonly used Ayurvedic preparations such as Kunkumadi Taila, Vanda Bhasma, Krmimudgara Rasa, Ayaskrti and Palasa Arka (The Ayurvedic Pharmacopoeia).

\section{TRADITIONAL USES}

As per the ancient Ayurvedic text book Charaka Samhita, seeds of Butea monosperma are insecticidal and Ayurvedic physicians used them to compound medicines for diarrhoea and dysentery. Juice made from the Butea monosperma roots, bark, and leaves are administered for regulating menstrual flow, colic and intestinal worms. The ointment made from the leaves is useful for boils, pimples, swellings, and for shrinking haemorrhoids. Flowers of Butea monosperma are useful as astringent, depurative and tonic (Patnaik, 1993).

\section{CHEMISTRY}

Butea monosperma flowers are known to contain flavonoids and glucosides. Butin, isobutrin and butein are main phytoconstituents of flowers. Chalcones, aurones, isobutyine, palasitrin, coreopsin, isocoreopsin (butin 7-glucoside), monospermoside and triterpene steroids are the other phytoconstituents present in the flower (Basu et al., 1999; Mishra et al., 2000). It also contains myricyl alcohol, stearic, palmitic, arachidic, lignoceric acids, glucose, fructose, phenylalanine, aspartic acid, alanine and histidine (Sindhia et al., 2010). Roots contain glucose, glucosides, glycine, and aromatic compounds (Parashar et al.)The seed oil contains proteolytic and lypolytic enzymes, plant proteinase and polypeptidase. Seeds also contain butin, monospermoside, $\alpha$-Amyrin, $\beta$ - sitosterol and $\beta$-sitosterol- $\beta$ D-glucoside (Bhargava, 1986). Bark contains various tannins like Kino-tannic acid, pyrocatechin. It also contains gallic acid, butolic acid, palasitrin, butrin, alanind, allophanic acid, cyanidin, histidine, lupenone, lupeol, miroestrol, medicarpin, shellolic acid and palasimide (Nadkarni, 1976). Leaves contain glucoside, linoleic acid, palmitic lignoceric acid, 3-alphahydroxyeuph- 25enylheptacosanoate and 3,9-dimethoxypterocapan (Mishra et al., 2000). Gum contains tannins, pyrocatechin and mucilaginous material (Kirtikar et al., 1918) (Figure 2). 
<smiles>O=C1CC(c2ccc(O)c(CC3OC(CO)C(O)C(O)C3O)c2)Oc2cc(OC3OC(CO)C(O)C(O)C3O)ccc21</smiles>

Butrin<smiles>O=C(/C=C/c1ccc(O)c(O)c1)c1ccc(O)cc1O</smiles>

Butein<smiles>C[C@H]1CC[C@]2(C)CC[C@]3(C)C(=CCC4[C@@]5(C)CCC(O)C(C)(C)C5CC[C@]43C)C2[C@@H]1C</smiles>

$\alpha$-Amyrin<smiles>O=C(O)c1cc(O)c(O)c(O)c1</smiles>

Gallic acid<smiles>O=C(/C=C/c1ccc(O)c(CC2OC(CO)C(O)C(O)C2O)c1)c1ccc(OC2OC(CO)C(O)C(O)C2O)cc1O</smiles>

Isobutrin<smiles>O=C(/C=C/c1ccc(O)c(O)c1)c1ccc(OC2OC(CO)C(O)C(O)C2O)cc1O</smiles>

Coreopsin<smiles>CC[C@H](CC[C@H](C)[C@]12CC[C@H]3[C@@H](CC=C4C[C@@H](O)CC[C@]43C)[C@H]1[C@H]2C)C(C)C</smiles>

Beta-sitosterol

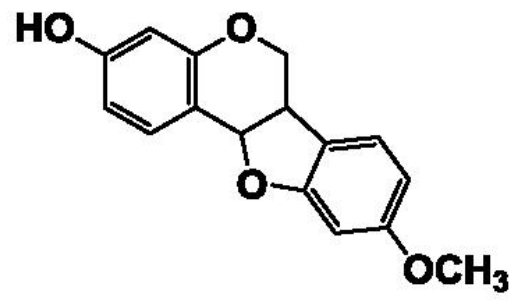

Medicarpin

Fig. 2: Chemical structure of the biologically active compounds of Butea monosperma.

\section{PHARMACOLOGICAL ACTIVITY}

\section{Anti-diabetic}

Ethanolic extract of Butea monosperma flowers significantly reduced blood glucose, serum cholesterol, improved HDL-cholesterol and increased the activities of antioxidant enzymes (Somani et al., 2006), (Talubmook et al., 2014), (Sharma et al., 2009). Similarly, methanolic extract of Butea monosperma flowers showed lipid lowering and anti-diabetic activity against high fat diet and streptozotocin induced diabetes in rats (Parveen et al., 2011). The n-butanolic fraction of Butea monosperma flowers significant decreased the dexamethasone induced hyperglycemia and hyperlipidemia in mice (Jamkhande et al., 2010). The ethanolic extract of Butea monosperma leaves elevated blood insulin level in Type 2 diabetic rats, stimulated insulin secretion in isolated rat islets, and enhanced hepatic glycogen formation. (Samad et al., 2014).

The leaves and stem bark of Butea monosperma showed significant anti-diabetic activity using various in vitro techniques viz. glucose adsorption, diffusion, amylolysis kinetics, enteric enzymes and glucose transport across yeast cells (Harish et al., 2014). The aqueous extract of Butea monosperma bark (Yadav et 
al., 2012), ethanolic extract of bark (Divya et al., 2014) and seeds (Bavarva et al., 2008) showed anti diabetic and lipid lowering activity in the rats. In addition, stigmasterol isolated from the bark of $B$. monosperma significantly reduced serum triiodothyronine, thyroxin, glucose and hepatic glucose-6- phophatase levels with a concomitant increase in insulin level (Panda et al., 2009). The oral administration of powder of Butea monosperma fruits at different dosage significantly reduced blood glucose, urine sugar, total lipids, LDL cholesterol and increased HDL cholesterol in both normal and diabetic subjects (Akhtar et al., 2010).

Table 1: Pharmacological effects of Butea monosperma (Lam.) Taub.

\begin{tabular}{|c|c|c|c|c|}
\hline $\begin{array}{l}\text { Pharmacological } \\
\text { Activity }\end{array}$ & $\begin{array}{l}\text { Plants } \\
\text { Parts } \\
\end{array}$ & Extract/Fractions & Doses & References \\
\hline \multirow{12}{*}{ Anti-diabetic } & \multirow{5}{*}{ Flowers } & \multirow{3}{*}{ Ethanolic extract } & $200 \mathrm{mg} / \mathrm{kg} \times 2$ weeks & Somani et al., 2006 \\
\hline & & & $250 \mathrm{mg} / \mathrm{kg} \times 8$ weeks & Talubmook et al., 2014 \\
\hline & & & $300 \mathrm{mg} / \mathrm{kg} \times 45$ days & Sharma et al., 2009 \\
\hline & & Methanolic extract & $300 \mathrm{mg} / \mathrm{kg} \times 4$ weeks & Parveen et al., 2011 \\
\hline & & n-butanolic fraction & $100 \mathrm{~g}$ and $200 \mathrm{mg} / \mathrm{kg} \times 22$ days & Jamkhande et al., 2010 \\
\hline & Leaves & Ethanolic extract & $2.5 \mathrm{~g} / 10 \mathrm{~mL}$ per kg body weight & Samad et al., 2014 \\
\hline & $\begin{array}{l}\text { Leaves and } \\
\text { Stem bark }\end{array}$ & Aqueous extracts & $\begin{array}{l}1-5 \mathrm{mg} / 1 \mathrm{~mL} \text { of glucose solution } \\
\text { (In vitro) }\end{array}$ & Harish et al., 2014 \\
\hline & \multirow{3}{*}{ Bark } & Aqueous extract & $1.25 \mathrm{mg} \times 4$ weeks & Yadav et al., 2012 \\
\hline & & Ethanolic extract & $500 \mathrm{mg} / \mathrm{kg}$ for 60 days & Divya et al., 2014 \\
\hline & & Isolated stigmasterol & $2.6 \mathrm{mg} / \mathrm{kg} \times 20$ days & Panda et al., 2009 \\
\hline & Seeds & Ethanolic extract & $300 \mathrm{mg} / \mathrm{kg} \times 4$ weeks & Bavarva et al., 2008 \\
\hline & Fruits & Powder & $1 \mathrm{~g}, 2 \mathrm{~g}$ and $3 \mathrm{~g} / 30 \mathrm{ml}$ for 30 days & Akhtar et al., 2010 \\
\hline \multirow{6}{*}{ Anti-inflammatory } & \multirow{3}{*}{ Flowers } & $\begin{array}{l}\text { Hydroalcoholic extract } \\
\text { and butrin, isobutrin } \\
\text { enriched fraction }\end{array}$ & $\begin{array}{l}2.5 \mathrm{mg} / \mathrm{mL} \text { and } 0.39 \mathrm{mg} / \mathrm{ml} \\
\text { respectively }\end{array}$ & $\begin{array}{l}\text { Krolikiewicz-Renimel et al., } \\
2013\end{array}$ \\
\hline & & Isobutrin and butein & $1-60 \mu \mathrm{g} / \mathrm{ml}$ for $2 \mathrm{~h}$ & Rasheed et al., 2010 \\
\hline & & Methanolic extract & 600 and $800 \mathrm{mg} / \mathrm{kg}$ (one-hour prior) & Shahavi et al., 2008 \\
\hline & Bark & Flavonoid fraction & - & Muralidhar et al., 2010 \\
\hline & & Methanolic & 200 and $400 \mathrm{mg} / \mathrm{kg}$ (30min prior) & William et al., 2007 \\
\hline & & Butein & $0.1-10 \mu \mathrm{M}$ & Lau et al., 2010 \\
\hline \multirow{2}{*}{$\begin{array}{l}\text { Antioxidant and free } \\
\text { radical scavenging } \\
\text { activity }\end{array}$} & Flowers & $\begin{array}{l}\text { Ethyl acetate, butanol and } \\
\text { aqueous fractions }\end{array}$ & $10-100 \mu \mathrm{g} / \mathrm{ml}$ & Lavhale et al., 2007 \\
\hline & Leaf & Aqueous and ethanolic extract & $200-400 \mathrm{mg} / \mathrm{kg} \times 7$ days & Singh et al., 2015a \\
\hline \multirow{3}{*}{ Anti-cancer } & \multirow{3}{*}{ Flowers } & Aqueous extract & $0.1,0.3$ and $1 \mathrm{mg} / \mathrm{ml}$ & Choedon et al., 2010 \\
\hline & & Methanolic extract & 100 and $200 \mathrm{mg} / \mathrm{kg}$ & Sehrawat et al., 2006 \\
\hline & & n-butanol fraction & $10-1000 \mu \mathrm{g} / \mathrm{ml}$ & Ganeshan et al., 2015 \\
\hline \multirow{3}{*}{$\begin{array}{l}\text { Hepatoprotective } \\
\text { effect }\end{array}$} & Flowers & Aqueous extract & 200,400 and $800 \mathrm{mg} / \mathrm{kg}$, p.o. & Sharma et al., 2011 \\
\hline & \multirow{2}{*}{ Bark } & Methanolic extract & $200 \mathrm{mg} / \mathrm{kg}$ and $400 \mathrm{mg} / \mathrm{kg}$, p.ox 10 days & Sathish et al., 2011 \\
\hline & & Hydroalcholic extract & 100 and $200 \mathrm{mg} / \mathrm{kg}$ dose $\times 3$ days & Tiwari et al., 2011 \\
\hline \multirow{2}{*}{ Nephroprotective } & \multirow[b]{2}{*}{ Flowers } & Ethanolic extract & $200,400 \mathrm{mg} / \mathrm{kg} \times 14$ days & Sonkar et al., 2014 \\
\hline & & n-butanolic fraction & $100,200 \mathrm{mg} / \mathrm{kg} \times 28$ days & Sutariya et al., 2015 \\
\hline Anti-asthmatic & Flowers & n-butanolic fraction & 50,100 and $200 \mathrm{mg} / \mathrm{kg}$ i.p $\times 4$ days & Shirole et al., 2013 \\
\hline \multirow{4}{*}{ Anti-anthelmintic } & Leaves & $\begin{array}{l}\text { Alcohol and ethyl acetate } \\
\text { extracts }\end{array}$ & 25,50 and $100 \mathrm{mg} / \mathrm{mL}$ & Borkar et al., 2010 \\
\hline & \multirow{3}{*}{ Seeds } & Methanol extract & $600,800,1000$ and $1200 \mu \mathrm{g} / \mathrm{ml}$ & Prashanth et al., 2001 \\
\hline & & Crud powder & 1,2 and $3 \mathrm{~g} / \mathrm{kg} \times 1$ day & Iqbal et al., 2006 \\
\hline & & Aqueous extracts & $100 \mathrm{mg} / \mathrm{ml} \times 6 \mathrm{~h}$ & Singh et al., $2015 \mathrm{~b}$ \\
\hline \multirow{3}{*}{ Anticonvulsant activity } & \multirow{2}{*}{ Flowers } & Acetone-soluble & 50 and $100 \mathrm{mg} / \mathrm{kg}$ i.p. & Kasture et al., 2000 \\
\hline & & Triterpene & $10-100 \mathrm{mg} / \mathrm{kg}$, i.p. & Kasture et al., 2002 \\
\hline & Lark and Leaf & Ethanolic extract & 250 and $500 \mathrm{mg} / \mathrm{kg}$ i.p. & Sangale et al., 2015 \\
\hline Anti-diarrhoeal & Bark & Ethanolic extract & 200,400 and $800 \mathrm{mg} / \mathrm{kg}$ & Gunakkunru et al., 2005 \\
\hline \multirow{3}{*}{ Wound healing } & \multirow{3}{*}{ Bark } & Flavonoid fraction & 25 and $50 \mathrm{mg} / \mathrm{kg}$ & Muralidhar et al., 2013 \\
\hline & & Alcoholic extract & - & Sumitra et al., 2005 \\
\hline & & Ethanol and aqueous extracts & - & Gavimath et al., 2009 \\
\hline \multirow[b]{2}{*}{ Anti-filarial } & Leave and Roots & Aqueous extract & $20-100 \mathrm{ng} / \mathrm{ml}$ for $24 \mathrm{hrs}$ & Sahare et al., 2012 \\
\hline & Leaves & $\begin{array}{l}\text { Methanol and hexane-ethanol } \\
\text { extract }\end{array}$ & 0.25 to $10.0 \mathrm{mg} / \mathrm{mL}$ & Deshmukh et al., 2014 \\
\hline \multirow{2}{*}{ Anti-ulcer } & Bark & Methanol extract & 100,250 and $500 \mathrm{mg} / \mathrm{kg}$ & Patil et al., 2008 \\
\hline & Bark & - & 100,250 and $500 \mathrm{mg} / \mathrm{kg}$ & Mhatre et al., 2014 \\
\hline Anti-stress & Flowers & Ethanolic extract & $(100,200$ or $400 \mathrm{mg} / \mathrm{kg})$ & Bhatwadekar et al., 1999 \\
\hline Anti-dopanergic & Flowers & Isoflavone & 50 and $100 \mathrm{mg} / \mathrm{kg}$ & Velis et al., 2008 \\
\hline Osteogenic activity & Bark & $\begin{array}{l}\text { Medicarpin, cajanin, } \\
\text { formonentin, isoformonentin }\end{array}$ & 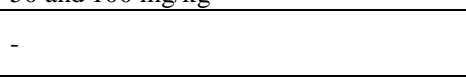 & Maurya et al., 2009 \\
\hline & Bark & Cajanin & $10 \mathrm{mg} / \mathrm{kg} \times 30$ days & Bhargavan et al., 2009 \\
\hline Contraceptive & Seeds & Butin & 5,10 and $20 \mathrm{mg} / \mathrm{kg}$ & Bhargava, 1986 \\
\hline Sunscreen activity & Seed & Powder & $2 \mathrm{~g} / \mathrm{kg}$, p.o. $\times 3$ days & Gupta et al., 2010 \\
\hline & Leaves & - & $0.5,1$ and $1.5 \%$ & More et al., 2013 \\
\hline
\end{tabular}


The hydroalcoholic extract of Butea monosperma flowers and butrin, isobutrin enriched fraction were able to decrease the secretion of pro-inflammatory cytokines, matrix metalloproteinase and prostaglandin production (Krolikiewicz-Renimel et al., 2013). Similarly, flavonoids rich fraction of Butea monosperma stem bark possesses anti-inflammatory activity by modulating cyclooxygenase and lipoxygenase enzymes and augmenting antioxidant defence system in the inflammation bearing rat (Muralidhar et al., 2010). The methanolic extract of Butea monosperma flowers inhibited the carrageenan induced paw edema and cotton pellet induced granuloma formation (Shahavi et al., 2008). Similarly, the methanolic extract of Butea monosperma stem bark exhibited anti-inflammatory activity in a dose dependant manner on carrageenan induced paw (William et al., 2007). The butrin, isobutrin, and butein isolated from Butea monosperma flowers significantly reduced the phorbol 12- myristate 13-acetate (PMA) and calcium ionophore A23187-induced inflammatory gene expression and production of TNF- $\alpha$, IL-6, and IL-8 in Human Mast Cells by inhibiting the activation of NF-kB (Rasheed et al., 2010). Similarly, butein isolated from Butea monosperma flowers significantly inhibited PMA -induced COX-2 expression in the non-tumorigenic MCF-10A and cancerous MCF-7 breast cells by inhibiting ERK and p-MAPK followed by inhibition in total activity of PKC (Lau et al., 2010).

\section{Antioxidant and free radical scavenging activity}

The ethyl acetate, butanol and aqueous fractions from total methanolic extract of Butea monosperma flowers possess free radical scavenging activity (Lavhale et al., 2007). The aqueous and ethanolic leaf extracts of Butea monosperma do contain compounds capable of inhibiting the cyclophosphamide induced oxidative stress and subsequent DNA damage in both the peripheral blood and bone marrow cells in mice (Singh et al., 2015a).

\section{Anti-cancer}

The aqueous extract of Butea monosperma flowers inhibited cell proliferation and accumulation of hepatoma cell in G1 phase with significance induction of apoptotic cell death suggesting chemopreventive and anti-cancer property (Choedon et al., 2010). Similarly, the pre-treatment of methanolic extract of Butea monosperma have chemopreventive effects on 2acetylaminofluorine induce hepatic carcinogenesis (Sehrawat et al., 2006). In vitro and In silico docking data suggested that the nbutanol fraction of Butea monosperma floral extracts potential anticancer activity (Ganeshan et al., 2015).

\section{Hepatoprotective effect}

The aqueous extract of Butea monosperma flowers restored serum transaminases, hepatic lipid peroxidation, reduced glutathione and total protein levels against $\mathrm{CCl}_{4}$ induced acute liver injury (Sharma et al., 2011). The methanolic extract of stem bark of Butea monosperma also showed significant hepatoprotective effect $\mathrm{CCl}_{4}$ induced acute liver injury (Sathish et al., 2011). The hydroalcholic extract of the stem bark of Butea monosperma have significant hepatoprotective effect $\mathrm{CCl}_{4}$ induced toxicity (Tiwari et al., 2011).

\section{Nephroprotective}

Ethanolic extract of Butea monosperma significantly inhibited the levels of serum creatinine, serum urea and blood urea nitrogen in gentamicin induced nephrotoxicity (Sonkar et al., 2014). The n-butanolic fraction of Butea monosperma flowers significantly reduced proteinuria, hypoalbuminemia, dyslipidemia and restored renal antioxidant enzyme activities in doxorubicin induced nephrotic syndrome (Sutariya et al., 2015).

\section{Anti-asthmatic}

n-butanolic fraction of Butea monosperma inhibited the lipopolysaccharide induced increase in total cell count, nitratenitrite, total protein and albumin levels in bronchoalveolar fluids in rats (Shirole et al., 2013).

\section{Anti-anthelmintic}

The alcoholic and ethyl acetate extracts of Butea monosperma leaves exhibited significant in vitro anthelmintic activity against earth worms, roundworm and tapeworms (Borkar et al., 2010). The methanolic extract of Butea monosperma seeds exhibited significant in vitro anthelmintic activity against Caenorhabditis elegan (zwild strain, N2 type) (Prashanth et al., 2001). The crude powder of Butea monosperma seeds exhibited significant in vitro anthelmintic activity in sheep naturally infected with mixed species of gastrointestinal Trichostrongylid nematodes (Iqbal et al., 2006). The aqueous extracts of Butea monosperma seeds exhibited anthelmintic efficacy against Haemonchus contortus of sheep and goats (Singh et al., 2015b).

\section{Anti-convulsive}

The acetone-soluble part of the petroleum ether extract of Butea monosperma flowers exhibited anticonvulsant activity (Kasture et al., 2000). Further studies revealed that the triterpenes isolated from the n-hexane:ethyl acetate fraction of Butea monosperma flowers have anticonvulsant activity in pentylenetetrazol induced seizures (Kasture et al., 2002). The ethanolic extract of Butea monosperma bark and leaf exhibited anticonvulsant effect in pentylene tetrazole and maximal electro shock seizure models (Sangale et al., 2015).

\section{Anti-diarrhoeal}

The ethanolic extract of stem bark of Butea monosperma inhibited castor oil induced diarrhoea and $\mathrm{PGE}_{2}$ induced enterpooling in rats. it also reduced gastrointestinal motility after charcoal meal administration (Gunakkunru et al., 2005).

\section{Wound healing}

The ethanol and aqueous extracts of Butea monosperma stem bark possess wound-healing properties in experimental animals (Gavimath et al., 2009). The flavonoid fraction of Butea 
monosperma stem bark showed wound healing property. (Muralidhar et al., 2013).

The ethanolic extract and the acetone fraction of Butea monosperma stem bark showed the significant wound healing activity which was evident by the increased rate of wound contraction, reduction in the period of epithelialisation and increase in collagen deposition (Muralidhar et al., 2011). The alcoholic bark extract of Butea monosperma accelerated wound healing action by increasing cellular proliferation and collagen synthesis at the wound site, as evidenced by increase in DNA, total protein and total collagen content of granulation tissues (Sumitra et al., 2005)

\section{Anti-filarial}

The aqueous extract of Butea monosperma leave and roots showed significant inhibition of motility of brugia malayi microfilariae as compare to control suggesting anti-filarial effects (Sahare et al., 2012). The methanolic and hexane-ethanolic extracts of Butea monosperma plant leaves showed significant antifilarial activity in terms of motility inhibition assay and MTTreduction assay (Deshmukh et al., 2014).

\section{Anti-microbial}

The hydro-alcoholic flower extract of Butea monosperma has shown antibacterial activity against pathogenic bacteria viz., Escherichia coli (Sharma et al., 2013). Similarly, the leaf-extracts of Butea monosperma with hot water and ethanol has shown significant antibacterial activity against all bacteria (Sahu et al., 2013). The various bioactive flavonoids like dihydrochalcone and dihydromonospermoside from Butea monosperma flowers along with butein, monospermoside and isoliquiritigenin have shown anti-mycobacterial activity (Chokchaisiri et al., 2009). The ethanolic extract of dried flowers and seeds of Butea monosperma have strong antimicrobial activity against standard cultures of Escherichia coli, Pseudomonas aeruginosa, Shigella flexneri, Salmonella typhi, and Salmonella paratyphi (Tambekar et al., 2010). The hexane: ethanol combination extract has shown antimicrobial activity against multidrug resistant bacteria including staphylococcus aureus, Bacillus cereus, Pseudomonas aeruginosa and Escherichia coli (Lohitha et al., 2010).

\section{Anti-ulcer}

The methanolic extract showed significant recovery against aspirin and ethanol induced gastric ulcerations suggesting anti-ulcer and anti-secretary potential. The stem bark of Butea monosperma markedly inhibited the acid output, the number of lesion along with reduction in volume of gastric juice, reflecting a positive effect of Butea monosperma on indomethacin induced gastric ulcers (Mhatre et al., 2014 )

\section{Anti-stress}

The water soluble part of ethanolic extract of Butea monosperma attenuated water immersion stress induced elevation of brain serotonin and plasma corticosterone level comparable to diazepam (Bhatwadekar et al., 1999).

\section{Anti-dopanergic}

The isoflavone isolated from methanolic extract of flowers of Butea monosperma has antidopaminergic activity. They found that the antidopaminergic activity is present in the ethyl acetate fraction isolated from methanolic extract of Butea monosperma flowers (Velis et al., 2008).

\section{Osteogenic activity}

The medicarpin, cajanin, formonentin, isoformonentin and cladrin isolated from stem bark of Butea monosperma have shown promicing osteogenic activity (Maurya et al., 2009). Similarly, Cajanin from Butea monosperma bark increased bone mineral density at all skeletal sites studied, bone biomechanical strength, mineral apposition rate (MAR) and bone formation rate (BFR), compared with control. (Bhargavan et al., 2009).

\section{Contraceptive}

Butin isolated from the seeds of Butea monosperma possesses postcoital anti-implantation and anti-conceptive activity in the pregnant rats during the implantation period. (Bhargava, 1986). Similarly, the administration of Butea monosperma seed powder caused disintegration of ova in the ovaries. Most of the follicle in immature state with undefined nucleus and nucleoli in the ovum (Gupta et al., 2010).

\section{Sunscreen activity}

The formulated cream containing the leaves extract of Butea monosperma has potency to protect against UVA and UVB rays indicating sunscreen activity as well the formulations produced by incorporating different concentration of extracts can be applicable for different type of Skin respectively as per SPF (Sun Protection Factor) value (More et al., 2013).

\section{Protease inhibitor activity}

The protease inhibitor isolated from the seeds of Butea monosperma (BmPI) possesses measurable inhibitory activity on total gut proteolytic enzymes of Helicoverpa armigera and bovine trypsin. These detrimental effects on Helicoverpa armigera suggest the usefulness of BmPI in insect pest management of food crops (Pandey et al., 2014).

\section{CONCLUSION}

The present review shows the pharmacological, traditional and phytochemical activities of Butea monosperma. The plant Butea monosperma has an excellent potential against various ailments and have been experimentally and clinically utilized in both animals and man. Further relevant studies are necessary to determine the mechanism by which Butea monosperma exhibit medicinal potential and these effects need to be confirmed using clinical trials for its effective utilization as therapeutic agents.

\section{REFERENCES}

Akhtar MS, Naeem F, Muhammad F, Bhatty N. Effect of Butea monosperma (Lamk.) Taub.(Palas papra) fruit on blood glucose and lipid 
profiles of normal and diabetic human volunteers. Afr J Pharm Pharmacol, 2010; 4:539-44.

Basu BD, Kirtikar K, Blatter E. 1999. Indian medicinal plants.end. International Book Distributors.

Bavarva J, Narasimhacharya A. Preliminary study on antihyperglycemic and antihyperlipaemic effects of Butea monosperma in NIDDM rats, Fitoterapia. 2008; 5: 328-31.

Bhargava S. Estrogenic and postcoital anticonceptive activity in rats of butin isolated from Butea monosperma seed. J Ethnopharmacol, 1986; 1:95-101.

Bhargavan B, Gautam AK, Singh D, Kumar A, Chaurasia S, Tyagi AM. Methoxylated isoflavones, cajanin and isoformononetin, have non-estrogenic bone forming effect via differential mitogen activated protein kinase (MAPK) signaling, J Cell Biochem, 2009; 2: 388-99.

Bhatwadekar A, Chintawar S, Logade N, Somani R, Veena KS, Kasture S. Antistress activity of Butea monosperma flowers. Indian J Pharmacol 1999; 2: 153.

Borkar V, Gangurde H, Gulecha V, Bhoyar P, Mundada A. Evaluation of in vitro antihelmintic activity of leaves of Butea monosperma. Int J Phytomed, 2011; 1:31-35.

Burlia D, Khadeb A. A comprehensive review on Butea monosperma (Lam.) Kuntze. Pharmacog Rev, 2007; 2:333-37.

Choedon T, Shukla SK, Kumar V. Chemopreventive and anticancer properties of the aqueous extract of flowers of Butea monosperma. J Ethnopharmacol, $2010 ; 2: 208-13$.

Chokchaisiri R, Suaisom C, Sriphota S, Chindaduang A, Chuprajob T, Suksamrarn A. Bioactive flavonoids of the flowers of Butea monosperma. Chem Pharm Bull, 2009; 4: 428-32.

Deshmukh M, Sahare KN, Patidar K, Mahajan B, Singh V. Antifilarial activity of Butea monosperma L. leaves extracts against Setaria cervi. Trends in Vector Research and Parasitology, 2014; 1: 1-5.

Divya B, Mini S. Ethanol extract of Butea monosperma bark modulates dyslipidemia in streptozotocin-induced diabetic rats. Pharm Biol, 2014; 8:1021-1027.

Ekor M. The growing use of herbal medicines: issues relating to adverse reactions and challenges in monitoring safety. Front in Pharmacol, 2013; 4:1-10.

Ganeshan M, Polachi N, Nagaraja P, Subramaniyan B. Antiproliferative Activity of n-butanol floral extract from Butea monosperma against HCT 116 Colon Cancer Cells; Drug Likeness Properties and In silico evaluation of their active compounds toward glycogen Synthase Kinase-3ß/Axin And B-Catenin/T-Cell Facto. Asian J Pharm Clin Res, 2015; 1:134-141.

Gavimath C, Sudeep H, Ganapathy PS, Rai SP, Ramachandra Y. Evaluatio of wound healing activity of butea monosperma lam. extracts on rats. Pharmacologyonline, 2009; 2: 203-216.

Gunakkunru A, Padmanaban K, Thirumal P, Pritila J, Parimala G, Vengatesan N. Anti-diarrhoeal activity of Butea monosperma in experimental animals. J Ethnopharmacol, 2005; 3:241-4.

Gupta N, Singh G, Singh S, Reddy K. Histologicos changes in overies of mice exposed to Butea monosperma: preliminary study. Int $\mathbf{J}$ Morphol, 2010; 4:1309-1314.

Gurib-Fakim A. Medicinal plants: traditions of yesterday and drugs of tomorrow. Mol Aspects Med, 2006; 1:1-93.

Harish M, Ahmed F, Urooj A. In vitro hypoglycemic effects of Butea monosperma Lam. leaves and bark. Int J Food Sci Tech, 2014; 2:308-314.

Hocking D. 1993. Trees for drylands. International science publisher. http://t.docsford.com/document/1536992. [Accessed 06 auguset 2014].

Iqbal Z, Lateef M, Jabbar A, Ghayur MN, Gilani AH. In vivo anthelmintic activity of Butea monosperma against Trichostrongylid nematodes in sheep. Fitoterapia, 2006; 2:137-140.

Jamkhande P, Patil P, Surana S. Evaluation of n-butanolic fractions of Butea monosperma flowers on dexamethasone induced hyperglycemia and hyperlipidemia in mice. Intl $\mathbf{J}$ of Phyto Pharm Res, 2010; 1:5-10.
Kasture V, Chopde C, Deshmukh V. Anticonvulsive activity of Albizzia lebbeck, Hibiscus rosa sinesis and Butea monosperma in experimental animals. J Ethnopharmacol, 2000; 1: 65-75.

Kasture VS, Kasture S, Chopde C. Anticonvulsive activity of Butea monosperma flowers in laboratory animals. Pharmacol Biochem Be, 2002; 4: 965-72.

Khare CP. 2007. Indian Medicinal Plants: An Illustrated dictionary Springer-Verlag Berlin: Heidelberg.

Kirtikar KR, Basu BD. 1918. Indian medicinal plants. Indian Medicinal Plants.

Krolikiewicz-Renimel I, Michel T, Destandau E, Reddy M, André P, Elfakir C. Protective effect of a Butea monosperma (Lam.) Taub. flowers extract against skin inflammation: Antioxidant, anti-inflammatory and matrix metalloproteinases inhibitory activities. J Ethnopharmacol, $2013 ; 2: 537-543$.

Lau GTY, Huang H, Lin S-m, Leung LK. Butein downregulates phorbol 12-myristate 13-acetate-induced COX-2 transcriptional activity in cancerous and non-cancerous breast cells. Euro J Pharmacol. 2010; 1:2430.

Lavhale MS, Mishra S. Evaluation of free radical scavenging activity of Butea monosperma Lam. Indian J Exp Biol, 2007; 4:376.

Lohitha P, Kiran VR, Babu KM, Nataraj K, Rani PA, Madhavi $\mathrm{N}$. Phytochemical screening and in vitro antimicrobial activity of Butea monosperma bark ethanolic and aqueous extract. Int J Pharm Sci Res, 2010; 1: 150-155.

Maurya R, Yadav DK, Singh G, Bhargavan B, Murthy PN, Sahai M. Osteogenic activity of constituents from Butea monosperma. Bioorg. Med Chem Lett, 2009; 3:610-613.

Mishra M, Shukla YN, Kumar S. Euphane triterpenoid and lipid constituents from Butea monosperma. Phytochem. 2000; 8:835-838.

More B, Sakharwade S, Tembhurne S, Sakarkar D. Evaluation of Sunscreen activity of Cream containing Leaves Extract of Butea monosperma for Topical application. Int J Cosmetic Sci, 2013; 3:1-6.

Muralidhar A, Babu KS, Sankar TR, Reddanna P, Latha J. Evaluation of wound healing properties of bioactive fractions from the extract of Butea monosperma (lam) stem bark. Int J Phytomed, 2011; 3: 41-49.

Muralidhar A, Babu KS, Sankar TR, Reddanna P, Latha J. Wound healing activity of flavonoid fraction isolated from the stem bark of Butea monosperma (Lam) in albino wistar rats. Eur J Exp Biol, 2013; 3: $1-6$.

Muralidhar A, Sudhakar B, Ravishankar T, Reddanna P, Reddy G, Latha J. Anti-inflammatory activity of flavonoid fraction isolated from the stem bark of Butea monosperma (LAM): A mechanism based study. Int $\mathrm{J}$ of Phyto Pharmacol, 2010; 2:124-32.

Nadkarni KM. 1976. Indian materia medica with ayurvedic, unani-tibbi, siddha, allopathic, homeopathic, naturopathic \& home remedies, appendices \& indexes. Bombay, Popular Prakashan.

Panda S, Jafri M, Kar A, Meheta B. Thyroid inhibitory, antiperoxidative and hypoglycemic effects of stigmasterol isolated from Butea monosperma. Fitoterapia 2009; 2:123-126.

Pandey PK, Singh D, Singh S, Khan M, Jamal F. A nonhost peptidase inhibitor of $14 \mathrm{kDa}$ from Butea monosperma (Lam.) Taub. seeds affects negatively the growth and developmental physiology of Helicoverpa armigera. Biochem Res Int, 2014; 2:1-11.

Parashar B, Dhamija HK. Botanical, Phytochemical and Biological Investigation of Butea monosperma (Lam.) Kutze. Pharmacologyonlin, 2011; 3: 192-208.

Parveen K, Siddiqui WA. Protective effect of Butea monosperma on high-fat diet and streptozotocin-induced non-genetic rat model of type 2 diabetes: Biochemical and histological evidences. Int $\mathrm{J}$ Pharm Pharm Sci, 2011; 3:74-81.

Patil P, Prakash T, Shivakumar H, Pal S. Anti-Ulcer and antisecretory Properties of the Butea Monosperma (Lam) Bark Extract with Relation to anti-oxidant Studies. Iranian J Pharmacol Ther, 2008; 8: 1-6.

Patnaik N. 1993. The Garden of Life. An Introduction to the healing plants of India), New York. 
Prashanth D, Asha M, Amit A, Padmaja R. Anthelmintic activity of Butea monosperma. Fitoterapia, 2001; 4:421-422.

Ramawat K, Dass S, Mathur M. 2009. The chemical diversity of bioactive molecules and therapeutic potential of medicinal plants. Herbal Drugs: Ethnomedicine to Modern Medicine: Springer.

Rana F, Avijit M. Review on Butea monosperma. Int J Res Pharm Chem. 2012;2:1035-1039.

Rasheed Z, Akhtar N, Khan A, Khan KA, Haqqi TM. Butrin, isobutrin, and butein from medicinal plant Butea monosperma selectively inhibit nuclear factor- $\mathrm{\kappa B}$ in activated human mast cells: Suppression of tumor necrosis factor- $\alpha$, interleukin (IL)-6, and IL-8. J Pharmacol Exp Ther. 2010; 2: 354-363.

Sahare K, Anandhraman V, Meshram V, Meshram S, Singh V, Reddy M. Antifilarial Potential of Butea monosperma against microfilaria in vitro. Int. J Pharm Tech Res, 2012; 3: 1181-1184.

Sahu MC, Padhy RN. In vitro antibacterial potency of Butea monosperma Lam. against 12 clinically isolated multidrug resistant bacteria. Asian Pac J Trop Dis, 2013; 3 :217-226.

Samad MB, Kabir AU, D'Costa NM, Akhter F, Ahmed A, Jahan MR, et al. Ethanolic Extract of Butea monosperma Leaves Elevate Blood Insulin Level in Type 2 Diabetic Rats, Stimulate Insulin Secretion in Isolated Rat Islets, and Enhance Hepatic Glycogen Formation. J. Evid. Based Complementary Altern, 2014; 1-13.

Sangale P, Deshmukh D, Bhambere R. Anticonvulsant Effect of Leaf and Bark of Erythrina Variegata Linn and Butea Monosperma (LAM) Taub in different Experimental Convulsion Model in Rats. PharmaTutor, 2015; 5: 19-23.

Sathish R, Sravan P, Natarajan K, Sridhar N. Hepatoprotective and Anti Pyretic Activities of Methanolic Extract of Butea Monosperma Lam Stem Bark In Wister Rats. Asian J. Pharm. Res, 2011; 4:130-133.

Sehrawat A, Khan T, Prasad L, Sultana S. Butea monosperma and chemomodulation: Protective role against thioacetamide-mediated hepatic alterations in Wistar rats. Phytomedicine, 2006; 13: 157-163.

Shahavi V, Desai S. Anti-inflammatory activity of Butea monosperma flowers. Fitoterapia, 2008; 2: 82-5.

Shailendra S, Gurav D, Gulkari N. JD, and Arun, TP, Antimicrobial activity of Butea monosperma Lam. Int $\mathrm{J}$ Pharm Technology, 2008; 7: 23-4.

Sharma N, Garg V. Antihyperglycemic and antioxidative potential of hydroalcoholic extract of Butea monosperma Lam flowers in alloxan-induced diabetic mice. Indian J Exp Biol, 2009; 7: 571.

Sharma N, Shukla S. Hepatoprotective potential of aqueous extract of Butea monosperma against $\mathrm{CCl} 4$ induced damage in rats. Exp Tox Pathol, 2011; 7:671-676.

Sharma P, Pandey P, Gupta R, Roshan S, Jain AP, Sahu A. Physicochemical \& antibacterial evaluation of hydro-alcoholic flower extract of Butea monosperma lam. Inventi Rapid: Planta Activa. 2013.

Shirole R, Sutariya B, Kshatriya A, Saraf M. Mechanistic evaluation of Butea monosperma using in vitro and in vivo murine models of bronchial asthma. Int J Res Ayurveda \& Pharm, 2013; 4:322-331.
Sindhia V, Bairwa R. Plant review: Butea monosperma. Int J Pharm Clin Res, 2010; 2:90-94.

Singh A, Kaur M, Choudhary A, Kumar B. Effect of Butea monosperma leaf extracts on cyclophosphamide induced clastogenicity and oxidative stress in mice. Pharm. Res, 2015; 1: 85.

Singh G, Singh R, Verma P, Anand A. Anthelmintic efficacy of aqueous extract of Butea monosperma (Lam.) Kuntze against Haemonchus contortus of sheep and goats. J Parasit Dis, 2015b; 2: 200-205.

Somani R, Kasture S, Singhai AK. Antidiabetic potential of Butea monosperma in rats. Fitoterapia. 2006; 2:86-90.

Sonkar N, Ganeshpurkar A, Yadav P, Dubey S, Bansal D, Dubey N. An experimetal evaluation of nephroprotective potential of Butea monosperma extract in albino rats. Indian J Pharmacol. $2014 ; 46$ :109.

Sumitra M, Manikandan P, Suguna L. Efficacy of Butea monosperma on dermal wound healing in rats. The Int $\mathrm{J}$ Biochem Cell $\mathrm{B}$, 2005; 37: 566-573.

Sutariya B, Badgujar L, Somani S, Saraf M. Anti-nephritic potential of n-butanolic fraction of Butea Monosperma (Lam.) flowers on doxorubicin induced nephrotic syndrome in rats. J. Res. Ayurveda Pharm, 2015; 4: 478-488.

Talubmook C, Buddhakala N. Antioxidant and antidiabetic activities of flower extract from Butea monosperma (Lam.) Taub. J Biosciences, 2014; 1: 7-11.

Tambekar D, Khante B. Antibacterial properties of traditionally used medicinal plants for enteric infections by adivasi's (bhumka) in melghat forest (amravati district). Int J Pharm Sci Res. 2010;1:120-8.

Tiwari P, Kumar K, Panik R, Pandey A, Pandey A, Sahu PK. Hepatoprotective potentials of Butea monosperma stem bark extract against carbon tetrachloride induced hepatotoxicity in albino rats. Res $\mathbf{J}$ Pharmacol Pharmacodyn, 2011; 5: 281-284.

The Ayurvedic Pharmacopoeia of India Part- I Volume - II p.78.

Velis H, Kasture A, Maxia A, Sanna C, Mohan M, Kasture S, editors. Antidopaminergic activity of isoflavone isolated from Butea monosperma flowers. Planta Medica, 2008; 1:159-168.

William CM, Krishna Mohan G. Antiinflammatory and analgesic activity of Butea monosperma (Lam) stem bark in experimental animals. Pharmacologyonline, 2007; 2: 88-94.

Yadav S, Chaturvedi N, Sharma S, Murthy R, Dwivedi KN. Antidiabetic effect of aqueous extract of butea monosperma (LAM) Taub bark. Food Sci, 2012 ; 42A: 6562-6567.

\section{How to cite this article:}

Brijesh Kantilal Sutariya, Madhusudan Natvarla Saraf. A Comprehensive review on Pharmacological Profile of Butea monosperma (Lam.) Taub. J App Pharm Sci, 2015; 5 (09): 159166. 